\title{
Prevention Destruction of Pancreatic B-Cells Caused "by Diabetogenic Zinc-binding chemicals by Amino acids Contains of SH-Radical in Structure of Molecule
}

\author{
Meyramov GG*, Shaybek AS and Dupont ON \\ Diabetes Research Group, Karaganda State Medical University, Russia
}

Received: 制: September 10, 2018; Published: 制 October 01, 2018

*Corresponding author: Gabit G Meyramov, Diabetes Research Group, Karaganda State Medical University Karaganda, Kazakhstan, Russia

Abstract

Authors investigated toxic properties of diabetogenic derivatives of 8-hydroxyquinoline (8-OX) and of Diphenyl thiocarbazone (DZ) on the insulin producing cells of the pancreas and the protective effect of Glutathione on its toxic action. The mechanism of action of derivatives of 8-0X determined by the ability to form into cells containing zinc-ions a chelate salts with them 1:1 by sulfur and nitrogen atoms at positions 8 and 1 and through the oxygen atoms in positions 8 and 2. Diphenyl thiocarbazone formed chelates salts with zinc as 2:1, where in zinc coupled to the two atoms via Dithizone sulfur and nitrogen atoms. It is shown that the preventing effect has GRF, containing in structure of SH-radical unlike GOF, not containing it. It is found that administration of CRF to animals $1000 \mathrm{mg} / \mathrm{kg}$ comp- letely protect B-cells of destruction determined by blocking of zinc by CRF. Results showed that this effect determined by blocking of zinc in B-cells by GRF. Authors suggest that atom of Zinc is fixed between atom of sulfur of the SH-radical and of atom of oxygen or nitrogen as after injections of 8-OX or DZ islet zinc binding too through atom of sulfur and oxygen.

Keywords: B-cells; Reduced form of Glutathione; Insulin; Zinc; Experimental Diabetes

Abbreviations: Zn: Zinc; DZ: Diphenylthiocarbazone (Dithizon); 8PTSQ: 8 para(toluenesulphonylmino)quinolin; GRF: Reduced form of Glutathione; GOF: Oxidized form of Glutathione

\section{Introduction}

\section{Background}

Diphenyl thiocarbazone (Dithizon) and some derivatives of 8-oxyquinolin (8-ox) induced formation of toxic chelat complexes as "Zn-DZ" and "Zn-8-ox" in cytoplasm of B-cells that result selective destruction of B-cells within 15-30min. and accompanied by developing of 1 st type diabetes in animals [1]. Later it was reported preventive injection of some amino acids as Cystein, L-Hystidine and Reduced form og Glutathione contains sulfhydril SH-radical in structure of molecule, accompanied by prevention B-cells of destruction caused by DZ and 8-ox that result prevention of developing of diabetes in majority of animals [2-5]. High durability of the $\mathrm{Zn}+2$-Dithizon complex 2:1 (Figures $1 \& 2$ ) determined by space elongation of molecule of Dithizon and disposition of two phenolic rings on the ends of a molecule that does not prevent the atoms of sulfur and nitrogen located in the center of a molecule to approach zinc atom. Besides, atom of zinc is located between two atoms of nitrogen and sulfur, regarding to which affinity of zinc is very high and exceeds affinity to oxygen [6]. It was supposed that protective activity of Cystein and L-Hystidine may be determined by the presence of SH-radical in the structure of molecule because formation of chelate complexes with DZ and 8-ox is processed by connection of $\mathrm{Zn}$ atoms with atom of $\mathrm{S}, \mathrm{H}, \mathrm{O}$ or $\mathrm{N}$ [6].

\section{Aim of Investigation}

To study possible preventive effect of amino acid Glutathione Reduced form on model of isolated pancreatic islets.

\section{Methods}

a) Animals: abbits $2400-2850 \mathrm{~g}$.

b) Group 1: Injection of Dithizon, 48,6-51,2 mg/kg;

c) Group 2: Injection of GRF, 970-1010 mg/kg + $10 \mathrm{~min}$. later Dithizon, 49,8-50,6 mg/kg.4 ani- mals from groups 1 and 2 were killed 10 min. after injection of Dithizon $(1 \mathrm{a} ; 2 \mathrm{a})$ and 4 animals - 9 days after injection (1b;2b).

d) Group 3: Injection of GOF $965 \mathrm{mg} / \mathrm{kg}$. Animals killed 15 min later. Staining Zinc in frozen sections of pancreas by 8PTSQ/

e) Group 4: Injection of GRF $1030 \mathrm{mg} / \mathrm{kg}$. Animals killed 15 min later. Staining Zinc in frozen sections of pancreas by 8PTSQ. 
Frosen sections of pancreas of animals $1 \mathrm{a}$ and $1 \mathrm{~b}$ groups were investigated using dark micro- scopy. Blood glucose level measuring - in animals of $1 \mathrm{~b}, 2 \mathrm{a}$ and $2 \mathrm{~b}$ groups before injection of Dithi- zon and 1,3,6 and 9 days after injection. Aldehyde-fucshine method [79] was used for analysis state of histostructure of pancreas tissue and Dithizon method formed red granules of complex "Zn-DZ" visible using dark microscopy. Maximum of absorbance of $\mathrm{Zn}+2$ DZ complex on spectrum of absorbance correspond for 530nm [3]. 8-para(toluenesulphonylamino)quinolin/8PTSQ/, a high specific fluorescent reagent was used for staining of $\mathrm{Zn}$-ions in B-cells.
8TSQ formed fluorescent green complexes with $\mathrm{Zn}+2$-ions visible using fluorescent microscopy [10-12].

\section{Results}

\section{Group 1a}

Administration of DZ accompanied by formation of a large amount of red granules of Zn-Dithizon complex in cytoplasm of B-cells (Figure 1). Maximal concentration of granules located on the pole of B-cells contacted blood capillaries that correspond to concentration of deposited insulin.

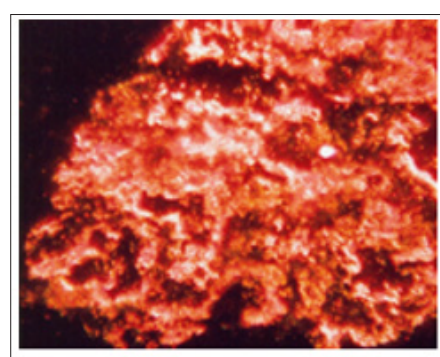

1

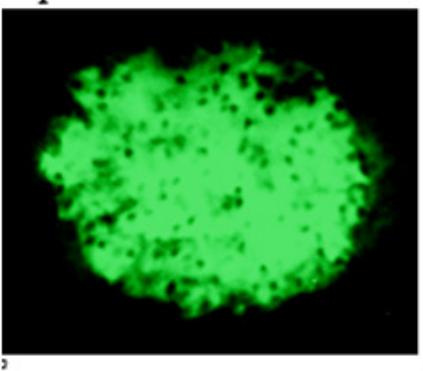

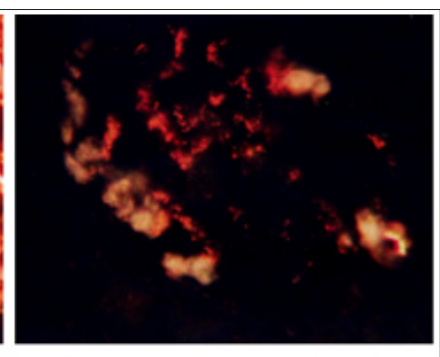

2

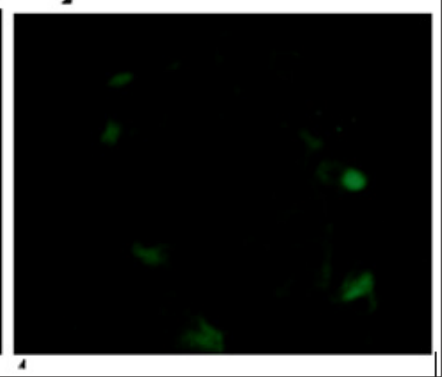

\section{Figure 1:}

a. Pancreatic islet of intact rabbit. Dithizon, $48,9 \mathrm{mg} / \mathrm{kg}$. Large amount of red granules of complex Zn-DZ in B-cells; Dark microscopy. x280.

b. Pancreatic islet. Glutathione Reduced form, $985 \mathrm{mg} / \mathrm{kg}+$ Dithizon, 50,2mg/kg. Almost complete absence of complex Zn-DZ in B-cells; Dark microscopy. x280.

c. Pancreatic islet. GOF, $1015 \mathrm{mg} / \mathrm{kg}$. Positive fluorescent reaction for Zn-ions in B-cells; x140.

d. Pancreatic islet. GRF $960 \mathrm{mg} / \mathrm{kg}$. Negative fluorescent reaction for Zn-ions in B-cells; x140

e. All histological preparats and microphotographs by Prof. Meyramov G.G.

\section{Group 1b}

Experimental diabetes. Blood glucose concentration increased since $5,2 \pm 0,3 \mathrm{mM}$ until $12,6 \mathrm{mM}$ at 6 th day and $16,4 \pm 1,7 \mathrm{mM}$ at 9th day (Table 1). Histology: necrosis and destruction of 70-90\% of B-cells, marked decreasing of insulin and zinc content in B-cells.

Table 1: Blood glucose concentration in rabbits after injection of Dithizon.

\begin{tabular}{|c|c|c|c|c|c|c|}
\hline \multirow{2}{*}{ Animals } & Dose of & \multicolumn{5}{|c|}{ Blood glucose concentration (mM) } \\
\cline { 3 - 7 } & $\mathbf{k g}$ & $\mathbf{b e f o r e}$ & $\mathbf{1}^{\text {st }} \mathbf{d a y}$ & $\mathbf{3}^{\text {rd }} \mathbf{d a y}$ & $\mathbf{6}^{\text {th }}$ day & $\mathbf{9}^{\text {th }}$ day \\
\hline 1 & 48,6 & 4,7 & 11,6 & 18,5 & 16,4 & 22,8 \\
\hline 2 & 49,9 & 5,6 & 7,7 & 16,2 & 24,4 & 21,5 \\
\hline 3 & 51,8 & 5,3 & 12,2 & 20,6 & 17,2 & 18,8 \\
\hline 4 & 48,8 & 5,9 & 10,3 & 14,6 & 20,5 & 17,8 \\
\hline
\end{tabular}

\section{Group 2a}

Preliminary injection of GRF result almost complete prevention of formation of "Zn-DZ" complex in B-cells (Figure 2).

\section{Group 2b}

Table 2: Blood glucose concentration after injection of GRF.

\begin{tabular}{|c|c|c|c|c|c|c|}
\hline \multirow{2}{*}{ Animals } & \multirow{2}{*}{$\begin{array}{c}\text { Dose of } \\
\text { GRF } \mathbf{~ m g} / \\
\mathbf{~ k g}\end{array}$} & $\begin{array}{c}\text { Dose of } \\
\text { DZ mg/ } \\
\mathbf{~ k g}\end{array}$ & \multicolumn{4}{|c|}{\begin{tabular}{c}
\multicolumn{4}{|c|}{ Blood glucose concen-tration } \\
(mM)
\end{tabular}} \\
\hline 1 & 985 & 49,3 & 5,9 & 6,7 & 6,2 & 5,8 \\
\hline 2 & 1010 & 50,6 & 5,1 & 7,1 & 5,3 & 5,9 \\
\hline 3 & 1012 & 52,2 & 4,3 & 6,1 & 5,7 & 6,8 \\
\hline 4 & 1020 & 50,8 & 5,5, & 7,2 & 6,6 & 5,7 \\
\hline
\end{tabular}

Cite this article: Meyramov GG, Shaybek AS, Dupont ON. Prevention Destruction of Pancreatic B-Cells Caused by Diabetogenic Zinc-binding chemicals by Amino acids Contains of SH-Radical in Structure of Molecule. Biomed J Sci\&Tech Res 9(3)-2018. BJSTR. MS.ID.001811. DOI: 10.26717/ BJSTR.2018.09.001811. 
Administration of GRF before Dithizon accompanied by prevention developing of diabetes in 3 animals from 4 (Table 2,3). In one rabbit (N3) blood Glucose level increase till 9th day until 7,3. Histologic analysis showed decreasing of insulin content in cells without marked histological changes.

Table 3: Blood glucose concentration after injection of GOF.

\begin{tabular}{|c|c|c|c|c|c|c|c|}
\hline & \multirow{2}{*}{ Animals } & \multirow{2}{*}{$\begin{array}{c}\text { Dose of } \\
\text { GOF }\end{array}$} & $\begin{array}{c}\text { Dose of } \\
\text { DZ } \mathbf{~ m g / ~} \\
\mathbf{k g}\end{array}$ & & \multicolumn{4}{|c|}{$\begin{array}{c}\text { Blood glucose concen-tration } \\
\text { (mM) }\end{array}$} & \\
\cline { 5 - 9 } & & & before & $1^{\text {st }}$ day & $\begin{array}{c}3^{\text {rd }} \\
\text { day }\end{array}$ & $\begin{array}{c}6^{\text {th }} \\
\text { day }\end{array}$ & $\begin{array}{c}9^{\text {th }} \\
\text { day }\end{array}$ \\
\hline 1 & 960 & 47,2 & 8,9 & 15,7 & 12,5 & 14,3 & 15,8 \\
\hline 2 & 1000 & 51,7 & 5,1 & 9,1 & 13,6 & 11,9 & 14,8 \\
\hline 3 & 1020 & 50,1 & 4,3 & 12,5 & 10,6 & 14,2 & 21,8 \\
\hline 4 & 1015 & 52,5 & 5,5 & 10,5 & 15,8 & 18,8 & 20,6 \\
\hline
\end{tabular}

\section{Group 3}

Injection of GOF: positive reaction for Zinc in B-cells with 8PTSQ (Figure 1).

\section{Group 4}

Injection of GRF: negative reaction for Zinc in B-cells as result of binding by GRF (Figure 1).

\section{Discussion}

Obtained results showed that administration of R-Glutathione result binding of almost all number of $\mathrm{Zn}$-ions in B-cells reversibly as least for 24 hours. Injection of dithizon after R-Glutathione not accompanied by forming in B-cells of chelate complexes Zn-DZ that result prevention of damage and death of majority B-cells and prevention developing of diabetes in 3 animals from 4 . It is known that amino acids Cystein and L-Hystidine possess same property: injection of acid result protects B-cells of destruction by Dithizon as of developing of diabetes in animals $[6,13,14]$. However, administration of Oxidized Glutathione not contains in structure of SH-radicals not protect B-cells of formation of Zn-DZ complex and of destruction of B-cells as of developing of diabetes [14]. Binding of $\mathrm{Zn}$-ions of diabetes B-cells by a glutathione is apparently confirmed by existence of negative reaction for $\mathrm{Zn}$ for 24 hours. After that the complex gradually dissociated up and 4872 hours later Dithizon is able to form in B-cells toxic complex that accompanied by developing of experimental diabetes in animals.

It is known that in process of formation of the $\mathrm{Zn}+2$-complex with Dithizon and diabetogenic derivatives of 8-oxyquinolin atom of zinc is fixed between $\mathrm{S}$ or $\mathrm{O}$ atoms in position 8 , and $\mathrm{N}$ or $\mathrm{O}$ atoms - in positions 1 or 2 (Figure 2) [15]. Diabetogenic derivatives of 8-oxyquinolin have in the 8 position of quinolin ring active $\mathrm{OH}$ - radical or other radicals contains atoms of $\mathrm{S}, \mathrm{N}$ or $\mathrm{O}$ (Figure 2). K Okamoto \& A Albert [15] reported showed that Dithizon (Diphenylthiocarbazone) and derivatives of 8-oxyquinolin which usually belong to not toxic substances, is very toxic for cells in the pre冈se囚nce of metals and for the first time - of Zn - ions. It was showed that this fact determined by ability of 8-oxy囚qu囚inolin to form with metals the chelat metal-complexes which are toxic for B-cells [15] as complexes formed in B-cells by other chelat active substance as Dithizon. Studying of toxicity of 8-oxy囚qui冈nolin for B-cells Oka冈moto $\mathrm{K}$ [1] reported that injection of it to animals accompanied by destruction of pancreatic B-cells and de区veloping of experimental diabetes. La冈ter it was showed that injection of 18 derivatives of 8-oxy冈quino冈lin (8-OXY) result formation in B-cells of color complexes Zinc-chelator destruction of B-cells that accompanied by destruction of B-cells within 15-30 min that result developing of 1st type diabetes in animals.

It was no囚ted that all 8-OXY contains in position 8 of quinolin ring $\mathrm{OH}$ - group or any other radical contai冈ns atom of $\mathrm{S}$ or atom of $\mathrm{O}$ or $\mathrm{N}$. I was showed that 8-OXY possess high affinity for Zinc and formed via radical in position 8 chelat salts with Zinc (Fig 2).Six iso冈mers of 8-oxyquinolin not contains in posi邓tion 8 of active group are not able to form chelat complexes with $\mathrm{Zn}$-ions and not induced experimental diabetes. Expe囚ri囚mental diabetes is induced by derivatives as 8-pa-ra(toluenesulphinylamino) quinolin/8PTSQ/,8-para(benzol『sulpho囚nylamino) quinolin /8PBSQ/, 8-para囚(me区thansulphonylamino) quinolin /8PMSQ/, 5 - para (acetamin ophenylso)-8-oxyqui囚no囚lin/5A80X/,8hydro®xy凶quinaldin,5-amino-8-ydroxyquinolin and others (Figure 2). It was demonstrated by Okamoto K. and Kado区ta I. that injection of these deri囚va邓tives result selective necrosis of B-cells. Injection of these che囚mic \als in doses of $30-100 \mathrm{mg} / \mathrm{kg}$ result developing within a few days of heavy diabetes with marked degenerative changes in islets $(1,3-4,11)$. It is known that most stable complexes are formed when atom of $\mathrm{Zn}$ is fixed bet囚we区en atoms of $\mathrm{S}$ and $\mathrm{O}$ in position 8 and between atoms of $\mathrm{N}$ and $\mathrm{O}$ in position 1 or 2 .

It was shwed that only derivatives of 8-oxyquinolin contai冈ned in po®sition 8 of qui冈nolin ring of the hydroxyl or other radical contained atoms of $\mathrm{S}, \mathrm{N}$ or $\mathrm{O}$ possess diabetogenic pro囚pe凶rties [15]. It is known, what is more, that extraction of these radicals from position 8 accompanied by complete disappearing of diabe区togenic properties of chelators [16]. Formation of chelats by atoms of $\mathrm{O}$ and $\mathrm{N}$ of chelator result usu凶ally forming of pentagonal or hexagonal rings [1,15] (Figure 1). Pentagonal rings are more stable. The most stable are quad囚rangular complexes with atom of S. It is known that derivatives of 8-oxyquinolin formed

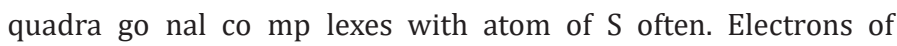
indivisible pair are displaced from donor-atom of $\mathrm{N}$ in position 1 to $\mathrm{Zn}$ atom. On the base of data obtained by A. Albert, G. Zentmyer supposed that toxic effect of 8-oxyqui-nolin is de区termined by its ability to bind and eliminate ions of metal from B-cells. But later this hypothesis was not confirmed: it was showed that long time prolonged elimination of $\mathrm{Zn}$-ions from B-cells result any effect on the state of histostructure and function of B-ce区l冈ls.

Finally, S.Rubbo and A.Albert established that toxic effect of 8-oxyquinolin determined by its ability to form in cells toxic complexes with metals [17] that many times was confirmed later. It was showed that pres囚e囚nce of chelat a short time in cytoplasm of B-cells accompanied by alteration of cells. In experiences with using derivatives of 8-oxyquinolin - a various isomers of the azaoxyquinolin (azaoxyn)- it was demonstrated dependence: most 
toxic are isomers formed chelats 1:1 with metal have loga冈rifm of constant of stability as 7.6 and high, until 9.4. Mean囚wखhile toxicity of chelats of other isomers of azaoxyn with constant of stability 5.8-6.7 was clearly more less $[5,15]$. It was showed that very toxic chelats of deri冈vatives of 8-oxyquinolin with $\mathrm{Zn}$-ions have a high loga囚ri冈fm of constant of stability as 8.5. Weitzel G.and coll. sho囚wed that complex 1:1 contained 1 molecule of 8-oxyquinolin and 1 atom of ion of $\mathrm{Zn}$ is most toxic for cells [18]. Stability of formed complexes 2:1 is depended not only of affinity of chelator to metal but by 2 properties of chelator and metal:

a. presence of additional radicals in para-positions molecule of chelator, especially - in zones which contacted with part of molecule, reacted with ions of metal conduce to forming of the steric effect; as result, two molecules of chelator are not able to approach for to put atom of metal in stable ring;

b. size of diameter of atom; in case if atom of metal has a small diameter, ring may be not formed; atom of $\mathrm{Zn}$ have radius as $0,74 \mathrm{~nm}$ between Berillium $(0,31 \mathrm{~nm})$ and Rubidium $(1,49 \mathrm{~nm})$.

A high stability of complex Zn-Dithizon is determined by stretch form of molecule of Dithizon and by location of 2 phenol rings on the 2 ends of molecule. That is why atom of $\mathrm{N}$ and $\mathrm{S}$ are easy approach to atom of $\mathrm{Zn}$. Moreover, atom of $\mathrm{Zn}$ is fixed between atoms of $\mathrm{N}$ and S. Meanwhile it is known that affinity of Zn to $\mathrm{N}$ and $\mathrm{S}$ is higher comparatively with affinity of $\mathrm{Zn}$ to $\mathrm{O}$. In added, complex is formed by two molecules of Dithizon each of two have a great number of double couplings $[1,5,15]$. Stability of complexes $1: 1$ formed by derivatives of 8-oxyquinolin is determined by great number of double coupling in molecule of chelator; by forming of quadragonal ring; derivatives of 8-arensulphonyl amino quinolin formed chelatecomplex by aid of atom of S. More high stability of the complex ZnXanthurenic Acid is determined in added by fixation of the atom of $\mathrm{Zn}$ between 2 atoms of 0 . Isomers of 8-oxyqunolines not contains in this position such radicals or atoms, or if these radicals extracted from a molecule - not capable to form complex salts with zinc and not possess completely diabetogenic properties. It is necessary to return the active radicals in position 8 for to restore diabetogenic activity of substance [16].

Formation of the chelate complex by atoms of $\mathrm{O}$ and $\mathrm{N}$ accompanied by forming of pentagonal or hexagonal rings [15]. SH group contains sulfur atom. Meanwhile, as described above, it is known that sulfur atom participates in formation of the chelate complexes with $\mathrm{Zn}$ as well as $\mathrm{N}, \mathrm{O}$ and $\mathrm{C}$ atoms. It is known that in process of formation of the $\mathrm{Zn}+2$-complex with Dithizon and diabetogenic derivatives of 8-oxyquinolin atom of zinc is fixed between $\mathrm{S}$ or $\mathrm{O}$ atoms in position 8 , and $\mathrm{N}$ or $\mathrm{O}$ atoms - in positions 1 or 2 (Figure 2) [15]. On the base of obtained results we suppose that negative fluorescent reaction for $\mathrm{Zn}$ in B-cells after administration of Glutathione Reduced form determined by binding of $\mathrm{Zn}$-ions via atom of sulfur of the SH-group and followed disposition of zinc atom between atom of sulfur and, probably, atom of oxygen or nitrogen (Figures 3 \& 4).

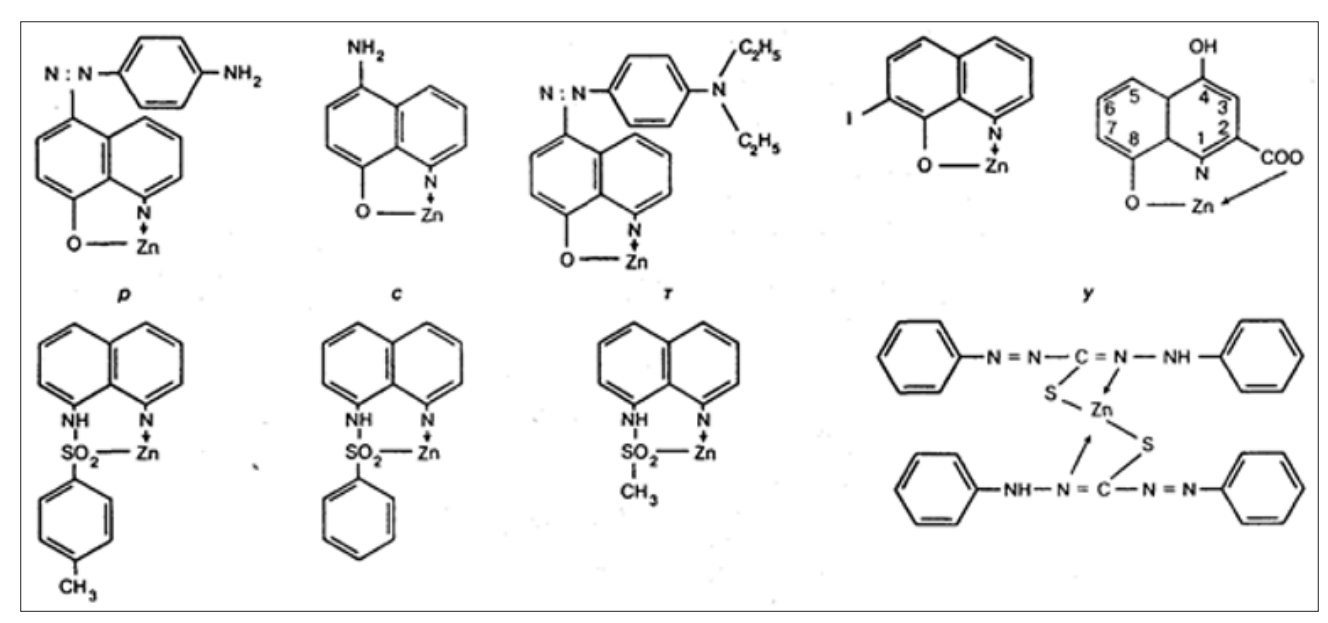

Figure 2:

Complex salts of Diabetogenic Zincbinding Chelat Active Chemicals with Zn-ions and its diabetogenic doses:

a. 2,4-dimethyl-8-oxyquinolin, 35mg/ kg; б) 5-phenylaso-8-oxyquinolin, $20 \mathrm{mg} / \mathrm{kg}$; в) 5-para (toluene)-8-oxyquinolin, $20 \mathrm{mg} / \mathrm{kg}$; г) 5-orto- (toluene)-8-oxyquinolin, $40 \mathrm{mg} / \mathrm{kg}$; д) $8-0 x y q u i n o l i n, 50-60 \mathrm{mg} / \mathrm{kg}$;

b. 5-para (diethylaminophenylaso)-8oxyquinolin, $20 \mathrm{mg} / \mathrm{kg}$; ж) 5-meta(hydroxyphenylaso)-8-oxyquinolin, 30mg/ $\mathrm{kg}$; 3) 5-para(dimethylaminophenylaso)-8-oxyquinolin, $45 \mathrm{mg} / \mathrm{kg}$; и) 5-para(acetylami- nophenylaso)-8-oxyquinolin, 50 $\mathrm{mg} / \mathrm{kg}$; к) 8-oxyquinaldin, 10mg/kg; л) 5-para (aminophenylaso)-8-oxyquinolin, 10mg/kg; м) 5-amino-8-oxyquinolin, $30 \mathrm{mg} / \mathrm{kg} ;$ н) 5-para (diethylaminophenyla- so)-8-oxyquinolin, 40mg/kg; o) 9-oxy-7-jodoquinolin, 50-60mg/kg; п) 4,8 dihydroxyquinolin-2 carboxylic acid (xantu- renic acid); p) 8-para (toluenesulphonylamino)quinolin, 30-50mg/kg;

c. $\quad$ 8-para( benzolsulphonylamino)quinolin, 30-100 mg/kg; т) 8-para (metansulphonylamino)quinolin, 40-81 mg/kg; y) diphenylthiocarbazone (dithizon), $45-50 \mathrm{mg} / \mathrm{kg}$. 


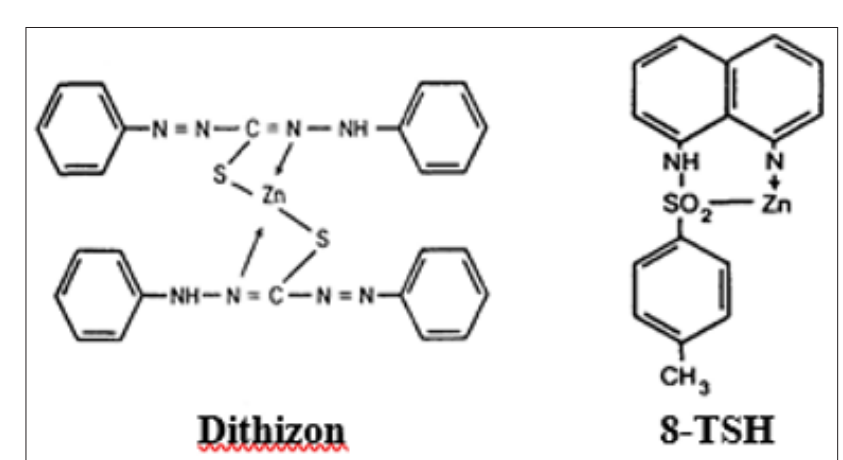

Figure 3: Chelat complexes Zn+2-Dithizon and Zn+2-8TSH.

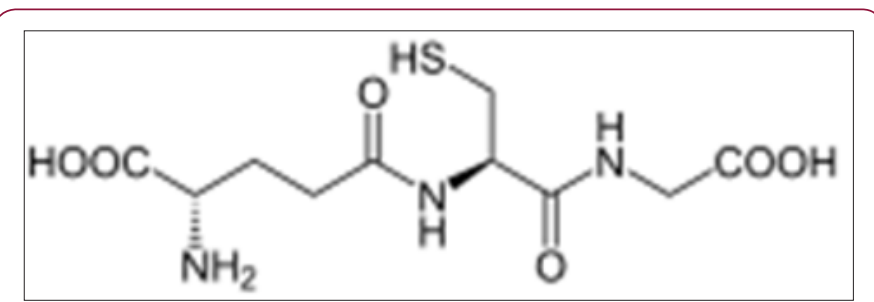

Figure 4: Chemical structure of GRF-Glutathione.

\section{Conclusion}

a. Amino acid Glutathione Reduced form contain in structure of SH-radical, $1000 \mathrm{mg} / \mathrm{kg}$ protect B-cells of formation complexes with diabetogenic zinc binding chelators and protect of destruction of B-cells as prevent developing of diabetes in animals.

b. Amino acid Glutathione Oxidized form not contain in structure of SH-radical, $1000 \mathrm{mg} / \mathrm{kg}$ not protect B-cells of formation complexes with diabetogenic zinc binding chelators and not protect B-cells of destruction and from developing of diabetes in animals.

c. Administration of Glutathione Reduced form to animals result blocking of $\mathrm{Zn}$-ions in B-cells that protect of interaction of metal with diabetogenic chelators.

d. We suppose that preventive effect after administration of Glutathione Reduced form determined by binding of Zn-ions via atom of sulfur of the SH-group and followed disposition of zinc atom between atom of sulfur and atom of oxygen or nitrogen.

\section{References}

1. Okamoto K (1970) Experimental production of diabetes. Diabetes mellitus: Theory and Practice, McGraw- Hill Book company pp. 230-255.
2. Kawanishi H (1966) Secretion of B-granules in islets of Langerhans in association with intracellular reactive zinc after administration of Dithizone in rabbits. Endocrinol Jap 13: 384-408.

3. Lazaris YA, Meyramov GG (1974) K mekhanismu povreshdeniya pankreatiches- kich octrovkov pri ditizonovom diabete [On the mechanisms of destruction of pancreatic islets in diabetes caused by Dithizon]. Bulletin Experimental Biologii I Meditsini Bull Exp Biol Med p. $19-22$.

4. Ultrastructure pancreas-ticheskih B-kletok pri ditizonovom diabete I ego predupreshdenii dietildithiokarbamatom natriy [Ultrastructure of pancreatic B-cells in diabetes caused by Dithizone and its prevention by Diethyl dithiocarbamic acid] Problem Endocrinology -Problems of Endocrinology p. 92-95.

5. Meyramova AG (2003) Diabetogenic zinksvyasivaushie B-zitotoksicheskie soedineniya [Diabetogenic zinc binding B-cytotoxic chemicals. Problem Endocrinology- Problems of Endocrinology 49 (2): 8-16.

6. Meyramov GG, Meyramova AG (2003) Cystein Protect Pancreatic B-cells of Destruction Caused by $\mathrm{Zn}+2$-chelators. DIABETES, the Journal of American Diabetes Association, USA, 5(1): 552

7. Kvistberg D, Lester G, Lasarov A (1966) Staining of insulin with aldehyde fuchsin. J Histochemical Cy Tochem 14: 609-611.

8. Ortman R, Forbes W, Balasubramanian A (1966) Concerning the staining properties of aldehyde basic fuchsin. J Histochemical 14: 104-111.

9. Orci L (1976) Some aspects of the morphology of insulin secreting cells. Acta Histochem 147-158.

10. Bogevolnov EA, Serebrakova GV (1961) 8-para(toluenesulphonylamino) quinolin, a fluorescent reagent for zinc and cadmium. Chemicals and drugs Moscow, p. 36-42.

11. Krasavin IA, Bavelsky SE, Lazaris YA, Dziomko VM (1969) Histochemical reaction for zinc in islets of Langerhans and diabetogenic activity of reagents. Problems of Endocrinology Moscow 102-105.

12. Meyramov GG (2017) Histochemical and Immunocytochemical Investigation of Endocrine Tissue of Pancreas after Damage Caused by B-cytotoxic Chemicals and its Prevention by L-Hystidine. Bulletin of the Karaganda State University Biology medicine 85: 60-71.

13. Meyramov GG, Meyramova AG (2003) Cystein Protect Pancreatic B-cells of Destruction Caused by $\mathrm{Zn}+2$-chelators. DIABETES, the Journal of American Diabetes Association, USA, 5(1): 552.

14. Meyramov GG, Meyramova AG (2004) Prevention of Diabetes Induced by Chelators by L-Hystidine. Diabetes the Journal of American Diabetes Association, USA, 52(6): 583.

15. Kotake Y, Kato T (1956) Inhibitory action of thereal sulfate of xanturenic acid and kynurenic acid with regard to its diabetogenic property. Proc Jap Acad 32: 361-363.

16. Rubbo S, Albert A (1950) Studies of diabetogenic action of 8-0xyquinolin. Brit J Exp Pathol 31: 425-428.

17. Weitzel G, Buddecke E, Strecker FJ (1954) Zinkbindungsvermogen and Blutzuckerwirkung von Xanthurensaure, Kynurenin und Tryptophan. Hoppe-Seyler's Z Physio 298: 169-184. 
ISSN: 2574-1241

DOI: 10.26717/BJSTR.2018.09.001811

Gabit G Meyramov. Biomed J Sci \& Tech Res

(C) (i) This work is licensed under Creative

Submission Link: https://biomedres.us/submit-manuscript.php

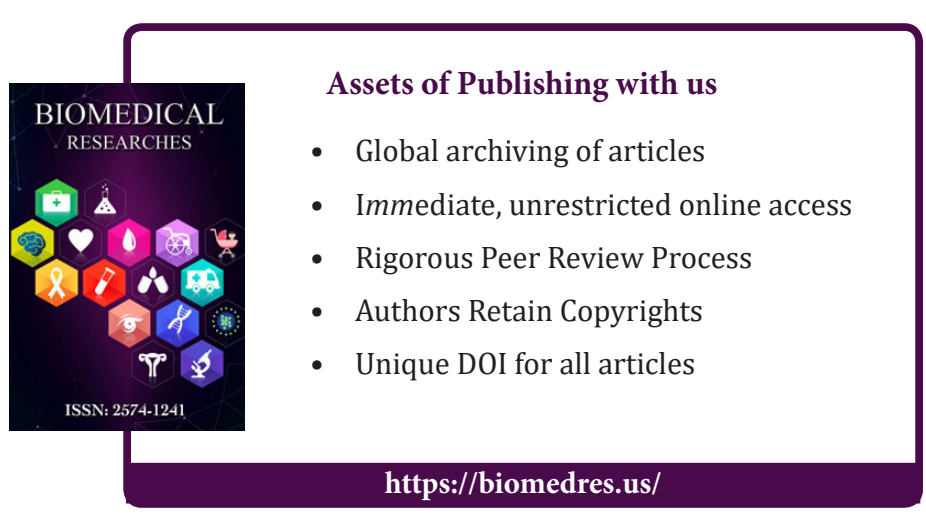

